Canadian

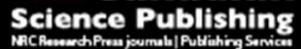

Canadian Journal of Forest Research Revue canadienne de recherche forestière

\title{
The legacy of deer overabundance: long-term delays in herbaceous understory recovery
}

\begin{tabular}{|r|l|}
\hline Journal: & Canadian Journal of Forest Research \\
\hline Manuscript ID & cjfr-2015-0280.R2 \\
\hline Danuscript Type: & Article \\
\hline Complete List of Authors: & $\begin{array}{l}\text { Pendergast, Thomas; University of Georgia, Plant Biology, Crop and Soil } \\
\text { Science; University of Pittsburgh, Department of Biological Sciences } \\
\text { Hanlon, Shane; University of Pittsburgh, Department of Biological Sciences } \\
\text { Long, Zachary; University of North Carolina Wilmington, Department of } \\
\text { Biology and Marine Biology } \\
\text { Royo, Alejandro (Alex); USDA Forest Service, } \\
\text { Carson, Walter; University of Pittsburgh, Department of Biological Sciences }\end{array}$ \\
\hline Keyword: & $\begin{array}{l}\text { white-tailed deer, Odocoileus virginianus, herbivory, understory, forest } \\
\text { recovery }\end{array}$ \\
\hline &
\end{tabular}


Title: The legacy of deer overabundance: long-term delays in herbaceous understory recovery

Authors: Thomas H. Pendergast $\mathrm{IV}^{1,2^{*}}$, Shane M. Hanlon ${ }^{1}$, Zachary M. Long ${ }^{3}$, Alejandro Royo ${ }^{4}$, Walter P. Carson ${ }^{1}$

${ }^{1}$ Department of Biological Sciences, University of Pittsburgh, A234 Langley Hall, 4249 Fifth Avenue, Pittsburgh, PA 15260, United States

${ }^{2}$ Current Address: Department of Crop and Soil Sciences, University of Georgia, 3111 Plant Sciences Building, Athens, GA 30602, United States

${ }^{3}$ Department of Biology and Marine Biology, University of North Carolina Wilmington, Friday Hall 2015, 601 South College Road, Wilmington, NC 28403, United States

${ }^{4}$ USDA Forest Service, Northern Research Station, Forestry Sciences Lab, P.O. Box 267, Irvine, PA 16329, United States

\section{Contact information}

20 Thomas H. Pendergast IV

21 Corresponding Author

28 Zachary T. Long

22 E-mail: thpiv@uga.edu

29 E-mail: longz@uncw.edu

23 Tel: +1-412-370-4524

30

24

25 Shane M. Hanlon

31 Alejandro Royo

26 E-mail:

32 E-mail: aroyo@fs.fed.us

27 shane.michael.hanlon@gmail.com

34 Walter P. Carson

35 E-mail:walt@pitt.edu

Running Title: Legacy of deer overabundance
Abstract Length: 195 words

Submission Type: Article

Manuscript Length: 2940 words

Number of References: 50

Number of Figures: 3

Number of Tables: 2

Number of Appendices: 2 
Abstract

Decades of white-tailed deer overpopulation have dramatically homogenized forests across much of the eastern United States, creating depauperate forest understory communities. It remains an open question the rate at which these communities recover once deer browsing has been reduced. We evaluate overbrowsing legacy effects by examining how forest herbaceous layers respond in terms of biodiversity, density, and community composition over 11 years using exclosures and control plots within a mature beech-maple forest. Although little recovery occurred in the first 5 years, total density and preferred-browse density rebounded substantially during the final years of the study. Although community composition began to diverge between exclosure and control plots after 5 years, diversity failed to recover even after 11 years of excluding browsers. Our findings show that vulnerable species can increase after excluding browsers but only if those species were initially present. Biodiversity recovery may be extremely slow because preferred browse species have been nearly extirpated from many forests and thus unable to recruit into refugia. We empirically demonstrate the extent of the ghost of herbivory past or legacy effect of browsing: the substantial time delay between herbivore abatement and community response after decades of high deer densities.

Keywords: white-tailed deer, Odocoileus virginianus, herbivory, understory, forest recovery 


\section{Introduction}

In many areas of the United States, the population density of white-tailed deer

(Odocoileus virginianus) has dramatically increased over the past century to levels significantly greater than pre-settlement estimates (Horsley et al. 2003; McCabe and McCabe 1997; Porter et al. 1994). Deer display browse preferences among forest plant species, largely based on plant chemical defenses and nutrient content (Augustine and McNaughton 1998; Berteaux et al. 1998; Dostaler et al. 2011; Whitney 1984). Prolonged and selective overbrowsing by deer has strong impacts on population and community level processes, including reducing recruitment, diminishing sizes, and shifting communities towards dominance by a small subset species that are browse-tolerant, browse resistant or both (Coté et al. 2004; Goetsch et al. 2011; Horsley et al. 2003; Rooney and Waller 2003; Waller 2014). In addition, in some cases, decades of overbrowsing can cause dramatic increases in browse tolerant species that can spread to form dense and recalcitrant understory layers (Royo and Carson 2006; Young and Peffer 2010).

These recalcitrant layers are often inimical to the recovery of vulnerable species even when browsing intensity is reduced or eliminated entirely (Royo and Carson 2006; Royo and Carson 2008). Consequently, under heavy browsing pressure, tolerant or resistant species will spread while palatable or preferred species will become uncommon and sparsely distributed across the landscape (for reviews, see Carson et al. 2014; Waller 2014)

Forest herbaceous species are especially sensitive to over-browsing by deer because they cannot reach a size refuge from browsers, as trees can. Thus they are often subjected to repeated bouts of browsing throughout their lifespans, which can severely reduce plant fecundity (Russell et al. 2001). Furthermore, strong herbivore pressures can severely limit sexual reproduction of perennial herbs by clipping flowers, fruit, or early reproductive tissue. For example, Comisky et 
111 al. (2005) found that reproductive individuals of several species of wildflowers were two orders

112 of magnitude more abundant on large boulders that served as refugia from deer versus adjacent

113 sites at the soil surface. If herbivore browsing levels remain consistently high, reproduction will

114 be limited or non-existent, and populations of perennial herbs are predicted to dwindle over time

115 (McGraw and Furedi 2005). Although patterns of low-diversity wildflower populations and

116 diminished reproduction are well documented, it remains an open question if plant communities

117 can rebound from chronic overbrowsing if herbivore populations are reduced or eliminated.

118 Long lag times in recovery are especially likely for many of these now low-density herbs due to

119 short dispersal distances, slow rates of growth and reproduction, as well as low genetic diversity,

120 Allee effects, and increased susceptibility to stochasticity (particularly physical disturbances,

121 e.g., Chips et al. 2014). Moreover, their former habitats may now be occupied by a dense and

122 recalcitrant layer of browse tolerant species.

Overall, the legacy of deer overabundance or ghost of herbivory past (Banta et al.

1242005 ) is likely to delay biodiversity recovery for decades or prevent recovery at all because

125 browsing may have created an alternative stable state (Banta et al. 2005; Carson et al. 2014;

126 Frerker et al. 2014; Royo et al. 2010b; Stromayer and Warren 1997; Tanentzap et al. 2009). In

127 fact, the few studies to date of sufficient duration to evaluate the length of legacy effects strongly

128 suggest that recovery will take decades, particularly for herbs and shrubs (Royo et al. 2010b;

129 Tanentzap et al. 2009). Here, we ask to what degree does excluding deer via exclosures lead to

130 understory recovery within a mature beech-maple forest over 11 years, in terms of plant density,

131 species richness, species diversity, and plant species composition. We predict that long-term

132 deer exclosures will act as refugia for preferred browse wildflower species, increasing the

133 frequency of browse-susceptible understory species and overall diversity over time, relative to 
134 areas that experience continual deer browse. However, we predict considerable lag times before 135 communities can recover from decades of intense herbivory.

\section{Materials and methods}

138 Site and deer densities: We conducted this experiment in Tryon-Weber Woods in

139 Crawford County, northwestern Pennsylvania, USA (latitude $41^{\circ} 36^{\prime} \mathrm{N}$ and longitude $80^{\circ} 21^{\prime} \mathrm{W}$ ).

140 This site is within a mesic temperate zone, with yearly rainfall averaging $103 \mathrm{~cm}$ and total

141 snowfall averages $165 \mathrm{~cm}$ (Linesville, PA weather station). This mature 10-ha beech-maple

142 forest is at least 100 years old and is stewarded by the University of Pittsburgh's Pymatuning

143 Laboratory of Ecology (please see Long et al. 2007 for forest structure details). This forest is

144 partially surrounded by younger secondary forest and exists within a landscape of forest

145 fragments, old-fields, and agriculture (Chips et al. 2014; Long et al. 2007). Although white-tailed

146 deer were nearly extirpated in western Pennsylvania in the late 1800 s, deer were reintroduced

147 and grew to large population densities by 1940 and have remained high (Heckel et al. 2010;

148 Smith 1989; Whitney 1984). Deer densities in Crawford County from 1996-1999 averaged $\sim 14$

149 deer $/ \mathrm{km}^{2}$ but summer densities were likely much higher (e.g., 29 deer $/ \mathrm{km}^{2}$, Wallingford 2000).

150 In this region, densities greater than $8 \mathrm{deer} / \mathrm{km}^{2}$ cause woody and herbaceous species declines

151 (Horsley et al. 2003).

152 Herbivore exclusion and plant sampling: Within Tryon-Weber Woods, twelve paired 153 plots, measuring 20m x 20m, were marked out in haphazard locations in March of 1996 (see

154 Chips et al. 2014; Long et al. 2007). Three meters separated paired plots, and treatment

155 (herbivore exclosure or control) was assigned randomly between plot pairs. Exclosure plots had

$1562.4 \mathrm{~m}$ tall fences with $5 \mathrm{~cm} \times 10 \mathrm{~cm}$ mesh constructed along their perimeter to exclude large 
157 herbivores. Within each plot, we established a $15 \mathrm{~m}$ x $15 \mathrm{~m}$ inner plot, subdivided into 9 subplots,

158 leaving a $2.5 \mathrm{~m}$ buffer around each inner plot. No major canopy gaps occurred across these plots

159 for the duration of the study. In late May or early June of 1997, 1998, 1999, 2001, and 2007, we

160 visually estimated the cover of each forb species using area templates of known size (e.g., 1\%,

$1615 \%$, etc.) in either 6 (randomly selected) or all 9 subplots within each large plot. Because visual

162 cover estimates can vary among observers among years, we also quantified stem densities in

1632001 and 2007. We used these data to calculate relative abundance (species cover/total cover),

164 plant density, species richness, Shannon diversity index (as measured by cover and density) and

165 community dissimilarity. We also grouped for analysis four species known to be preferred by

166 deer, specifically Maianthemum canadense, M. racemosa, Polygonatum pubscens and Trillium

167 grandiflorum (Comisky et al. 2005; Korschgen et al. 1980; Kraft et al. 2004; Mosbacher and

168 Williams 2009). Finally, we also evaluated the impact of exclosures on Podophyllum peltatum, a

169 dominant understory species that is unpalatable and never browsed (Cassidy et al. 1982).

170 Statistical analyses: We evaluated whether excluding browsers would alter density,

171 species richness, and diversity over time using Proc Mixed (SAS ver. 9.2, SAS Institute 2008)

172 and performed repeated measures ANOVAs with autoregressive covariance structure. For 2001

173 and 2007 data, we also performed an ANOVA on total density. Analyses were conducted at the

174 subplot level, with a random statement nesting subplot within plot. We used a Satterwaite

175 unequal variance mixed model with a repeated statement (Proc Mixed) to test the effect of deer

176 herbivory on preferred browse density over time (Ruxton 2006). We used identical methodology

177 to test the effect of deer removal on the density of Podophyllum peltatum.

178 To test if exclosures created contrasting communities over time, we used a semi-metric

179 Bray-Curtis dissimilarity index and nonparametric MANOVA, conducted in R (R Development 
180 Core Team 2011), using the vegan package and Adonis procedure (Oksanen et al. 2007). The

181 Bray-Curtis method and nonparametric MANOVA allow for binary and zero-inflated data sets as

182 well as situations where rare species lead to violations of assumptions of normality required for 183 parametric MANOVA (McArdle and Anderson 2001). The Bray-Curtis dissimilarity index (BC) 184 is

185

186

$$
B C=\frac{\sum_{i}\left|X_{i j}-X_{i k}\right|}{\sum_{i}\left(X_{i j}+X_{i k}\right)}
$$

where $\mathrm{Xij}$ is the abundance of the $i$ th species in treatment $j$ and $\mathrm{X}_{i k}$ is the abundance of

the $i$ th species in treatment $k$ (Krebs 1989). Additionally, we repeated the analysis with the Horn and Jaccard dissimilarity index to account for any abundance or sample size bias (Krebs 1989).

\section{Results}

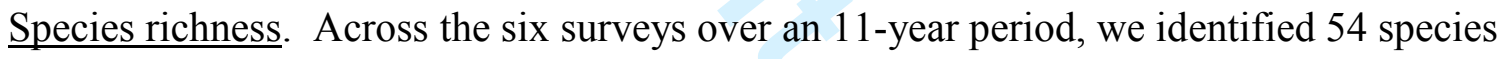

194 of herbaceous vines and forbs. In the final census in 2007, we found a total of 38 plant species, 19524 in control plots and 32 in fenced plots. Excluding deer caused a modest $(<2$ species $)$ but 196 significant increase $(\mathrm{p}=0.042)$ in mean species richness by 2007 but richness did not increase 197 relative to control plots until after 2001, at least seven years after the fences were built (Figure

198 1A, Table 1). Species richness also increased over time both inside the exclosures and in control 199 plots (Figure 1A, Table 1).

201 diversity (Figure 1B, Table 1) but it did increase over time when using both cover and stem 202 densities as abundance metrics $(\mathrm{p}=0.0233, \mathrm{p}<0.0001$, respectively Figure $1 \mathrm{~B}$, Table 1$)$. It is 203 important to point out that there was no significant exclosure by time interaction, thus even after 
20411 years there was no significant increase in Shannon diversity inside the exclosures (Figure 1B, 205 Table 1).

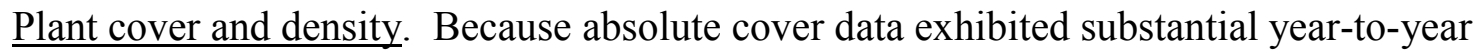

207 variability, we used our cover data only to look at patterns of relative abundance and community

208 composition using dissimilarity indices (see below). Cover estimates likely varied because of

209 observer bias among years or timing of sampling relative to the onset of warming during each

210 spring among years.

211 Five years after the exclosures were built, excluding browsers had not caused an increase

212 in total plant density or the density of preferred species (Figure 2A,B, Table 1). However, during

213 the next 6 years, excluding browsers caused substantial increases in plant density and nearly all

214 of this (83\%) was accounted for by an increase in the density of preferred species (Figure 2A,B

215 Table 1). It is important to note that total density and in particular preferred density also

216 increased significantly over time in control plots but increased most dramatically inside

217 exclosures (exclosure x time interaction for preferred species, Figure 2A,B Table 1).

218 Podophyllum peltatum, a species that deer never consume, was 2.5 times more dense in control

219 plots $(\mathrm{p}=0.0291$, Figure 2C, Table 1).

220 Plant community composition. Excluding browsers caused community composition to

221 diverge for all three community dissimilarity indices but only beginning in 2001, five years after

222 erecting the fences (Figure 3, Table 2). This was largely caused by the dominance of P. peltatum

223 in the control plots and the increase of preferred species, such as Mitchella repens inside the

224 exclosures (Figure 3). Mitchella repens was by far the most abundant species (by cover) inside

225 the exclosures by 2007. 


\section{Discussion}

228 Within large parts of the Eastern Deciduous Forest Biome, decades of overbrowsing has created

229 depauperate herbaceous communities dominated by browse-tolerant or resistant species (Frerker

230 et al. 2014; Nuttle et al. 2013; Rooney and Dress 1997). In some cases, some of these browse-

231 tolerant or browse-resistant species can spread to form dense and recalcitrant understory layers

232 that are inimical to biodiversity recovery (Royo and Carson 2006). What is far less clear is the

233 amount of time required for herbaceous understory communities to recover their lost diversity.

234 Here, we demonstrate that excluding deer for 11 years did not lead to a significant recovery of

235 biodiversity in terms of species richness or species diversity (Figure 1, Table 2). While species

236 richness did increase significantly inside the exclosures, this increase was modest. We did,

237 however, see a 4-fold increase in the combined density of four preferred species, which were

238 present in the understory at the start of the experiment (Figure 2B). Our results demonstrate that

239 preferred species, if they are present, will increase following the exclusion of deer but even these

240 preferred species showed no increase in density during the first five years of deer exclusion.

241 Overall, substantial diversity recovery will likely take much longer than the 11-year duration of

242 this experiment, especially under low light regimes of mature forest (Anderson et al. 1969). Our

243 data, coupled with a few other studies (Royo et al. 2010b; Tanentzap et al. 2011; Tanentzap et al.

244 2009) suggest that even if deer are reduced to zero (excluded) or near zero, lag times in

245 biodiversity recovery will last at least a decade and likely much longer. One bright spot is that

246 species composition inside the fences began to diverge from control plots after 5 years (Table 2)

247 suggesting that some recovery had begun.

248 We were only able to classify 4 species of over 50 as being preferred by deer (c.f. Vankat

249 and Snyder 1991). This is not surprising since deer have been over-abundant in the region for 
250 well over 50 years (Horsley et al. 2003) and depauperate understories are common throughout 251 the eastern deciduous forest (reviewed by Waller 2014) and, in particular, in Pennsylvania 252 (Carson et al. 2014). Thus, it was no surprise that Podophyllum peltatum, which is defended by 253 potent lignans and glycosides (Cassidy et al. 1982) was the dominant understory species in 254 control plots (Figure 3), and it increased in total density during the study (Figure 2C). It is now 255 well known that overbrowsing can lead to an increase in the abundance of resistant or tolerant 256 species and in some cases the formation of dense recalcitrant understory layers that are inimical 257 to biodiversity recovery (Carson et al. 2014; Royo and Carson 2006; Waller 2014; Young and 258 Peffer 2010). Indeed, Carson et al. (2014) demonstrated that even a stand replacement

259 disturbance or canopy gaps will cause few changes in understory diversity or abundance because 260 these disturbances occur over a depauperate understory created by nearly a century of 261 overbrowsing. In contrast, when deer are closer to historical levels, they can promote 262 herbaceous diversity following disturbance by acting as keystone species via reducing the 263 abundance of fast growing woody pioneers (Royo et al. 2010a).

264 One curious feature of our results is that plant species richness, diversity, and density

265 increased over time after 2000 in the control plots as well as inside exclosures (Figures 1 and 2).

266 Understory populations can certainly fluctuate with climate, pathogen outbreaks and non-

267 ungulate herbivory (and their interactions, McDowell et al. 2011) and control plots also had low 268 tree seedling densities that continued to decline over time $\left(0.24\right.$ and $0.04 \mathrm{stems} / \mathrm{m}^{2}$ in 1996 and 269 2005, Long et al. 2007), thus lack of competition may have aided herbaceous response.

270 However, seedling densities in enclosed plots increased but plateaued at $\sim 0.4 \mathrm{stems} / \mathrm{m}^{2}$ by 1999

271 (Long et al. 2007), a level that clearly did not significantly hinder population growth of

272 herbaceous species (Figure 2). The substantial herbaceous increase in control plots coincided 
273 with a statewide initiative by the Pennsylvania Game Commission designed to bring deer more

274 into balance with their habitat (Frye 2006). This initiative increased antlerless harvests statewide

275 by $55 \%$ and total deer harvests by $31 \%$ relative to rates in the 1990 's (Appendix A, compiled

276 from www.pgc.state.pa.us). This may provide a possible explanation for the observed increases

277 in richness and density outside of the exclosures after 2000. Unfortunately, this conservation-

278 oriented deer management program quickly floundered (Carson et al. 2014; Frye 2006) and deer

279 densities again began to rise in the latter part of the decade (Rosenberry et al. 2011). We should

280 note, however, that Tryon Webber Woods and other forests in the region remain depauperate

281 (Carson et al. 2014; Waller 2014) relative to forests without chronic deer overpopulation. For

282 example, Vankat and Snyder (1991) found 2 to 3 times the number of herbaceous species in

283 similar glacial moraine mature beech-maple forests in Ohio, where deer densities were

284 consistently under $1 \mathrm{deer} / \mathrm{km}^{2}$ for decades (ODNR 1996). This was true even though our

285 vegetation surveys cover $\sim 13$ times the area sampled by Vankat and Snyder (1991).

286 The next step in understanding legacy effects is to further quantify the severity of these

287 effects in regions both within the Eastern Deciduous Forest biome and biomes elsewhere (e.g.,

288 Wright et al. 2012). Perhaps, however, it is more important to parse out the myriad of potential

289 causes that underlie long lag times in biodiversity and community recovery. Understory species

290 face sparse distributions, slow growth rates, low fecundity, limited dispersal, and Allee effects

291 (Bierzychudek 1982; Handel et al. 1981; Matlack 1994). However, there may be an array of

292 additional hurdles including dense recalcitrant understory layers, low light levels, disruption of

293 mutualisms (e.g., arthropod seed dispersers, pollinators, and mycorrhizal fungi), invasive plant

294 species (e.g., garlic mustard) and exotic earthworms. Many of these factors may be operating

295 simultaneously. Though speculative, all of these factors together may be creating the perfect 
296 storm of events that contribute to the development of alternative stable states that may create

297 fundamentally different and depauperate forest herbaceous communities across broad regions

298 (Stromayer and Warren 1997). These communities are already forming for woody species

299 throughout the east (e.g., Nuttle et al. 2013) and in other temperate forests around the world

300 (Askins 2014; Wright et al. 2012).

\section{Conclusions}

302 The chronic high deer densities throughout many regions of the eastern United States have

303 critical implications for the current and future understory diversity. Our results strongly support

304 forest management techniques that decrease deer populations to promote viable understory

305 communities. Additionally, we must expect time lags on the scale of decades before herbaceous

306 populations can recover following a decrease in top-down pressure. Although refugia may

307 provide local seed sources to reestablish palatable species following herbivory abatement,

308 alternative successional pathways may result in lower diversity recalcitrant understories, with

309 herbivore sensitive species functionally extirpated.

\section{Acknowledgments}

312 Jill T. Anderson, Aileen Wertz, Chad Kirschbaum, Kelly A. Kumm, David M. Krayesky, Amy

313 Long, Andrea Quesada, Todd Ristau, and Garland Waleko and many others helped maintain the

314 exclosures and collect data. We thank J. Anderson for helpful comments and statistical advice.

315 The Pennsylvania Academy of Science, Sigma Xi, and the Pymatuning Laboratory of Ecology

316 provided financial support. 
320 Anderson, R.C., Loucks, O.L., and Swain, A.M. 1969. Herbaceous response to canopy cover, light intensity, and throughfall precipitation in coniferous forests. Ecology 50(2): 255-263. Askins, R.A. 2014. Saving the world's deciduous forests: ecological perspectives from East Asia, North America, and Europe. Yale University Press.

Augustine, D.J., and McNaughton, S.J. 1998. Ungulate effects on the functional species composition of plant communities: Herbivore selectivity and plant tolerance. Journal of Wildlife Management 62(4): 1165-1183.

Banta, J.A., Royo, A.A., Kirschbaum, C., and Carson, W.P. 2005. Plant communities growing on boulders in the Allegheny National Forest: evidence for boulders as refugia from deer and as a bioassay of overbrowsing. Natural Areas Journal 25(2): 10-18.

Berteaux, D., Crete, M., Huot, J., Maltais, J., and Ouellet, J. 1998. Food choice by white-tailed deer in relation to protein and energy content of the diet: a field experiment. Oecologia 115: 8492.

Bierzychudek, P. 1982. Life histories and demography of shade-tolerant temperate forest herbs a review. New Phytologist 90(4): 757-776.

Carson, W.P., Royo, A.A., and Peterson, C.J. 2014. A pox on our land: a case study of chronic deer overbrowsing throughout the Allegheny National Forest region in Pennsylvania. In The herbaceous layer in forests of eastern North America, 2nd Edition. Edited by F.S. Gilliam and M.R. Roberts. Oxford University Press, New York, New York, USA.

Cassidy, D.E., Drewry, J., and Fanning, J.P. 1982. Podophyllum toxicity - A report of a ratal case and a review of the literature. Journal of Toxicology-Clinical Toxicology 19(1): 35-44. Chips, M.J., Magliocca, M.R., Hasson, B., and Carson, W.P. 2014. Quantifying deer and turkey leaf litter disturbances in the eastern deciduous forest: have nontrophic effects of consumers been overlooked? Canadian Journal of Forest Research 44(9): 1128-1132.

Comisky, L., Royo, A.A., and Carson, W.P. 2005. Deer browsing creates rock refugia gardens on large boulders in the Allegheny National Forest, Pennsylvania. American Midland Naturalist 154(1): 201-206.

Coté, S.D., Rooney, T.P., Tremblay, J.P., Dussault, C., and Waller, D.M. 2004. Ecological impacts of deer overabundance. Annual Review of Ecology Evolution and Systematics 35: 113147. doi: 10.1146/annurev.ecolsys.35.021103.105725.

Dostaler, S., Ouellet, J., Therrien, J., and Côté, S.D. 2011. Are feeding preferences of whitetailed deer related to plant constituents? The Journal of Wildlife Management 75(4): 913-918. Frerker, K., Sabo, A., and Waller, D. 2014. Long-term regional shifts in plant community composition are largely explained by local deer impact experiments. PLoS One: e115843.doi:115810.111371/journal.pone.0115843.

Frye, R. 2006. Deer wars: science, tradition, and the battle over managing whitetails in Pennsylvania. Penn State University Press, University Park, PA. Goetsch, C., Wigg, J., Royo, A.A., Ristau, T., and Carson, W.P. 2011. Chronic over browsing and biodiversity collapse in a forest understory in Pennsylvania: results from a 60 year-old deer exclusion plot. The Journal of the Torrey Botanical Society 138(2): 220-224.

Handel, S.N., Fisch, S.B., and Schatz, G.E. 1981. Ants disperse a majority of herbs in a mesic forest community in New York state. Bulletin of the Torrey Botanical Club 108(4): 430-437. Heckel, C.D., Bourg, N.A., McShea, W.J., and Kalisz, S. 2010. Nonconsumptive effects of a generalist ungulate herbivore drive decline of unpalatable forest herbs. Ecology 91(2): 319-326. 
Horsley, S.B., Stout, S.L., and DeCalesta, D.S. 2003. White-tailed deer impact on the vegetation dynamics of a northern hardwood forest. Ecological Applications 13(1): 98-118.

Korschgen, L.J., Porath, W.R., and Torgerson, O. 1980. Spring and summer foods of deer int the Missouri Ozarks. Journal of Wildlife Management 44(1): 89-97.

Kraft, L.S., Crow, T.R., Buckley, D.C., Nauertzd, E.A., and Zasadae, J.C. 2004. Effects of harvesting and deer browsing on attributes of understory plants in northern hardwood forests, Upper Michigan, USA Forest Ecology and Management 199: 219-230. Krebs, C.J. 1989. Ecological methodology. Harper Collins, New York, New York, USA. Long, Z.T., Pendergast IV, T.H., and Carson, W.P. 2007. The impact of deer on relationships between tree growth and mortality in an old-growth beech-maple forest. Forest Ecology and Management 252: 230-238.

Matlack, G.R. 1994. Plant-species migration in a mixed history forest landscape in eastern North America. Ecology 75(5): 1491-1502.

McArdle, B.H., and Anderson, M.J. 2001. Fitting multivariate models to community data: a comment on distance-based redundancy analysis. Ecology 82: 290-297.

McCabe, T.R., and McCabe, R.E. 1997. Recounting whitetails past. In The science of overabundance: deer ecology and population management. Edited by W.J. McShea and H.B. Underwood and J.H. Rappole. Smithsonian Institutional Press, Washington D.C., USA. pp. 1126. The interdependence of mechanisms underlying climate-driven vegetation mortality. Trends in Ecology \& Evolution 26(10): 523-532.

McGraw, J.B., and Furedi, M.A. 2005. Deer browsing and population viability of a forest understory plant. Science 307(5711): 920-922. doi: 10.1126/science.1107036.

Mosbacher, E.V., and Williams, C.E. 2009. Browse preference and browsing intensity of whitetailed deer (Odocoileus virginianus) in Allegheny high plateau riparian forests, USA. Wildlife Biology in Practice 5: 11-21.

Nuttle, T., Royo, A.A., Adams, M.B., and Carson, W.P. 2013. Historic disturbance regimes promote tree diversity only under low browsing regimes in eastern deciduous forest. Ecological Monographs 83(1): 3-17. doi: 10.1890/11-2263.1.

394 Oksanen, J., Kindt, R., Legendre, P., O’Hara, B., and Stevens, M.H.H. 2007. VEGAN:

395 Community Ecology Package. In R package version 1.8-7.

396 Porter, W.F., Coffey, M.A., and Hadidian, J. 1994. In search of a litmus test: Wildlife 397 management in the U.S. National Parks. Wildlife Society Bulletin 22: 301-306.

398 Rooney, T.P., and Dress, W.J. 1997. Patterns of plant diversity in overbrowsed primary and 399 mature secondary hemlock northern hardwood forest stands. Journal of the Torrey Botanical 400 Society 124(1): 43-51.

401 Rooney, T.P., and Waller, D.M. 2003. Direct and indirect effects of white-tailed deer in forest ecosystems. Forest Ecology and Management 181(1-2): 165-176. doi: 10.1016/s03781127(03)00130-0. Rosenberry, C.R., Fleegle, J.T., and Wallingford, B.D. 2011. Monitoring deer populations in Pennsylvania. Bureau of Wildlife Management PGC.

Royo, A.A., and Carson, W.P. 2006. On the formation of dense understory layers in forests worldwide: consequences and implications for forest dynamics, biodiversity, and succession. Canadian Journal of Forest Research 36(6): 1345-1362. doi: 10.1139/x06-025. 
409 Royo, A.A., and Carson, W.P. 2008. Direct and indirect effects of a dense understory on tree 410 seedling recruitment in temperate forests: habitat-mediated predation versus competition.

411 Canadian Journal of Forest Research 38(6): 1634-1645.

412 Royo, A.A., Collins, R., Adams, M.B., Kirschbaum, C., and Carson, W.P. 2010a. Pervasive

413 interactions between ungulate browsers and disturbance regimes promote temperate forest

414 herbaceous diversity. Ecology 91(1): 93-105. doi: 10.1890/08-1680.1.

415 Royo, A.A., Stout, S.L., deCalesta, D.S., and Pierson, T.G. 2010b. Restoring forest herb

416 communities through landscape-level deer herd reductions: Is recovery limited by legacy effects?

417 Biological Conservation 143(11): 2425-2434. doi: 10.1016/j.biocon.2010.05.020.

418 Russell, F.L., Zippin, D.B., and Fowler, N.L. 2001. Effects of white-tailed deer (Odocoileus virginianus) on plants, plant populations and communities: A review. American Midland Ruxton, G.D. 2006. The unequal variance t-test is an underused alternative to Student's t-test and the Mann-Whitney U test Behavioral Ecology 17(4): 688-690.

Smith, T.L. 1989. An overview of old-growth forest in Pennsylvania. Natural Areas Journal 9(1): 40-44.

Stromayer, K.A.K., and Warren, R.J. 1997. Are overabundant deer herds in the eastern United States creating alternate stable states in forest plant communities? Wildlife Society Bulletin $\mathbf{2 5}$ : 227-234.

Tanentzap, A.J., Bazely, D.R., Koh, S., Timciska, M., Haggith, E.G., Carleton, T.J., and Coomes, D.A. 2011. Seeing the forest for the deer: Do reductions in deer-disturbance lead to forest recovery? Biological Conservation 144(1): 376-382. doi: 10.1016/j.biocon.2010.09.015. Tanentzap, A.J., Burrows, L.E., Lee, W.G., Nugent, G., Maxwell, J.M., and Coomes, D.A. 2009. Landscape-level vegetation recovery from herbivory: progress after four decades of invasive red deer control. Journal of Applied Ecology 46(5): 1064-1072. doi: 10.1111/j.13652664.2009.01683.x. Vankat, J.L., and Snyder, G.W. 1991. Floristics of a chronosequence corresponding to old fielddeciduous forest succession in southwestern Ohio. I. Undisturbed vegetation. Bulletin of the Torrey Botanical Club 118(4): 365-376. doi: 10.2307/2997088. Waller, D. 2014. Effects of deer on forest herb layers. In The herbaceous layer in forests of eastern North America, 2nd Edition. Edited by F.S. Gilliam and M.R. Roberts. Oxford University Press, New York, New York, USA.

Wallingford, B.D. 2000. Estimating county deer population sizes \& growth rates. Edited by P.G.C. Bureau of Wildlife Management.

Whitney, G.G. 1984. Fifty years of change in arboreal vegetation of Heart's Content, an oldgorwth hemlock white-pine northern hardwood stand. Ecology 65(2): 403-408.

Wright, D.M., Tanentzap, A.J., Flores, O., Husheer, S.W., Duncan, R.P., Wiser, S.K., and Coomes, D.A. 2012. Impacts of culling and exclusion of browsers on vegetation recovery across New Zealand forests. Biological Conservation 153: 64-71.

Young, T.P., and Peffer, E. 2010. "Recalcitrant understory layers" revisited: arrested succession and the long life-spans of clonal mid-successional species. Canadian Journal of Forest Research 40(1184-1188). 
Table 1. Response of species richness, herbaceous cover, and Shannon Diversity Index (1997, 1998, 1999, 2001, 2007) and total wildflower, preferred browse, and Podophyllum peltatum density (2001 and 2007) to deer exclosures, analyzed using a repeated measures ANOVA in SAS Proc Mixed. Boldface P-values indicate significance.

\begin{tabular}{l|l|l|l|}
\multicolumn{1}{c}{ Source of Variation } & F & DF $(\mathbf{N}, \mathbf{D})$ & \multicolumn{1}{c|}{ P } \\
\hline \multicolumn{4}{|c|}{ Species Richness } \\
\hline Exclosure & 4.24 & 1,106 & $\mathbf{0 . 0 4 2 1}$ \\
\hline Year & 13.52 & 4,266 & $<\mathbf{0 . 0 0 0 1}$ \\
\hline Exclosure x Year & 1.04 & 4,266 & 0.3868 \\
\hline
\end{tabular}

Shannon Diversity Index (by Cover)

\begin{tabular}{|l|l|l|l|}
\hline Exclosure & 3.59 & $1,86.5$ & 0.0615 \\
\hline Year & 5.29 & 1,109 & $<\mathbf{0 . 0 2 3 3}$ \\
\hline Exclosure x Year & 0.42 & 1,109 & 0.5177 \\
\hline
\end{tabular}

Shannon Diversity Index (by Density)

\begin{tabular}{|l|l|l|l|}
\hline Exclosure & 2.08 & 1,106 & 0.1518 \\
\hline Year & 7.5 & 4,266 & $<\mathbf{0 . 0 0 0 1}$ \\
\hline Exclosure x Year & 1.75 & 4,266 & 0.1389 \\
\hline
\end{tabular}

Total Density

\begin{tabular}{|l|l|l|l|}
\hline Exclosure & 12.19 & 1,176 & $\mathbf{0 . 0 0 0 6}$ \\
\hline Year & 39.16 & 1,176 & $<\mathbf{0 . 0 0 0 1}$ \\
\hline Exclosure x Year & 8.72 & 1,176 & $\mathbf{0 . 0 0 3 6}$ \\
\hline
\end{tabular}

Preferred Browse Density

\begin{tabular}{|l|l|l|l|}
\hline Exclosure & 9.7 & 1,108 & 0.0024 \\
\hline Year & 30.46 & 1,143 & $<\mathbf{0 . 0 0 0 1}$ \\
\hline Exclosure x Year & 9.43 & 1,108 & $\mathbf{0 . 0 0 2 7}$ \\
\hline
\end{tabular}

Podophyllum peltatum Density

\begin{tabular}{|l|l|l|l|}
\hline Exclosure & 4.87 & 1,127 & $\mathbf{0 . 0 2 9 1}$ \\
\hline Year & 14.74 & 1,154 & 0.0002 \\
\hline Exclosure x Year & 3.15 & 1,127 & 0.0784 \\
\hline
\end{tabular}


466 Table 2. Bray-Curtis, Jaccard, and Horn Indices of Community Dissimularity. Boldface P-

467 values indicate that fenced and unfenced herbaceous communities are significantly different.

\begin{tabular}{|c|c|c|c|c|c|c|}
\multicolumn{4}{c}{ Bray Curtis } & \multicolumn{2}{c|}{ Jaccard } & \multicolumn{2}{c|}{ Horn } \\
Year & F Model & P-value & F Model & P-value & F Model & P-value \\
\hline 1997 & 1.5976 & 0.1268 & 1.4106 & 0.0899 & 1.3872 & 0.2368 \\
\hline 1998 & 1.5551 & 0.1179 & 1.5017 & 0.9191 & 1.9215 & 0.1349 \\
\hline 1999 & 1.5576 & 0.1044 & 1.4640 & 0.0869 & 1.3921 & 0.2198 \\
\hline 2001 & 3.1071 & $\mathbf{0 . 0 0 9 0}$ & 2.2542 & $\mathbf{0 . 0 0 7 0}$ & 3.7531 & $\mathbf{0 . 0 0 4 2}$ \\
\hline 2007 & 2.5795 & $\mathbf{0 . 0 0 4 0}$ & 2.0240 & $\mathbf{0 . 0 0 1 0}$ & 2.5723 & $\mathbf{0 . 0 3 5 0}$ \\
\hline
\end{tabular}

468

469

470

471

472

473

474

475

476

477

478

479

480

481

482

483

484

485 


\section{Figure Captions}

487 Figure 1. Species richness and Shannon diversity indices of herbaceous understory species in 488 fenced and unfenced plots established in 1996, monitored from 1997 through 2007. The vertical 489 gray dashed line indicates when antlerless deer harvest was increased. (A) Species richness at $4905 \times 5 \mathrm{~m}$ subplot level. Species richness increased if protected from deer $(\mathrm{p}=0.0421)$ and over time

$491(\mathrm{p}<0.0001)$. (B) Shannon Diversity Indices did not differ in the first 5 years, but exclosure plots 492 showed only a trend of increased diversity by $2007(\mathrm{p}=0.0615)$, and increased over time $493(\mathrm{p}=0.0233)$. Relevant statistics presented in Table 1.

Figure 2. Subplot stem densities of all herbaceous understory species and preferred browse 496 species in fenced and unfenced plots established in 1996, monitored from 2001 through 2007.

497 (A) Stem density was significantly higher in the exclosure treatment in $2007(\mathrm{p}=0.006)$, but also 498 increased over time $(\mathrm{p}<0.0001)$. (B) Preferred browse density increased with deer exclosure and 499 over time, but increased most dramatically in protected plots (Fence x Year: $p=0.0027) .(\mathbf{C})$

500 The herbivore resistant Podophyllum peltatum density increased over time $(\mathrm{p}=0.0002)$ but ore 501 substantially in control plots $(\mathrm{p}=0.0291)$. Relevant statistics presented in Table 1.

503 Figure 3. Relative abundance (by total cover) of herbaceous species in control and exclosure 504 plots from 1997 to 2007 . We have identified by genus the 10 most abundant species in the 2007 505 control plots in the legend; all other abundance data can be found in Appendix B. These two 506 wildflower communities are significantly disparate (Bray-Curtis Community Dissimilarity Index, $507 \mathrm{p}=0.001)$ 


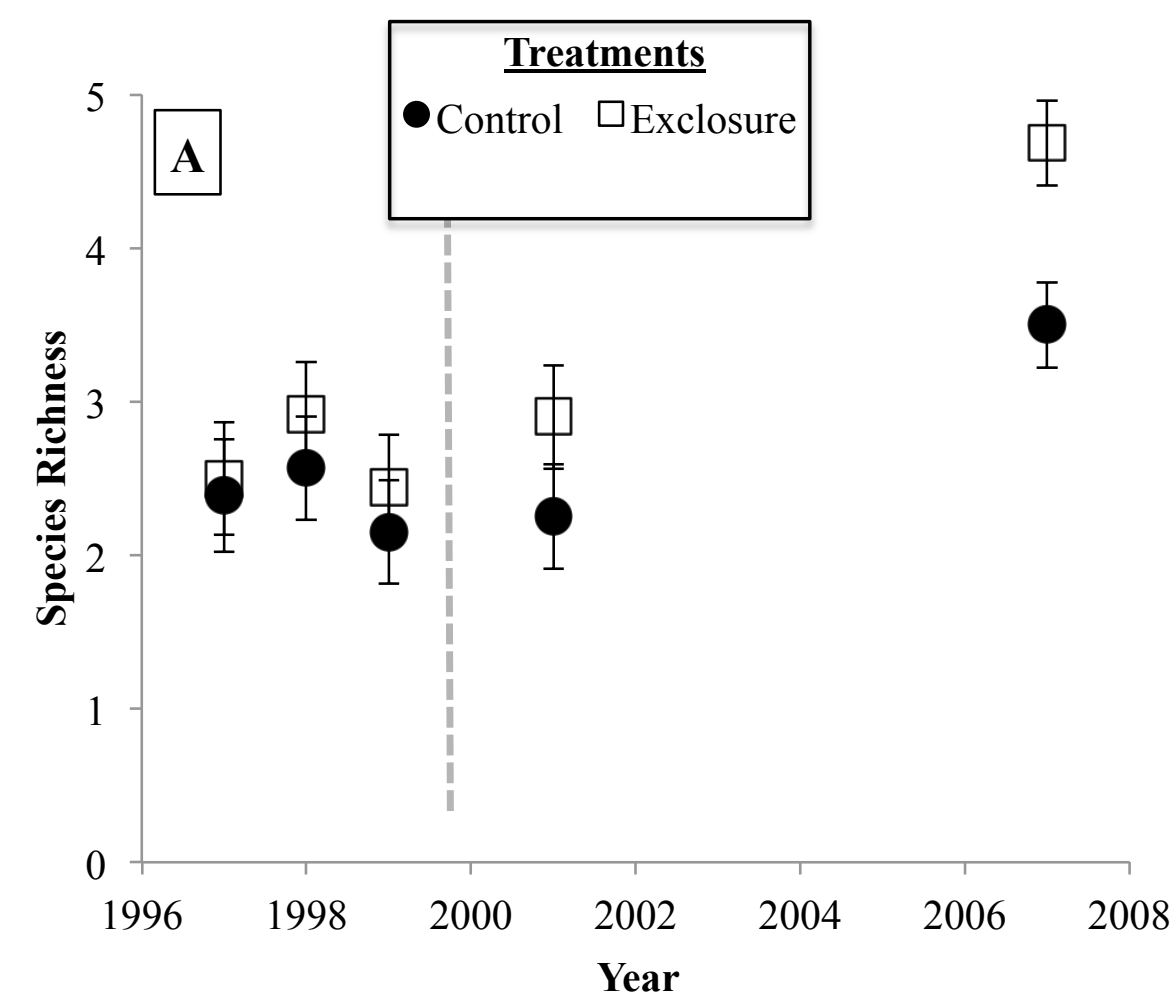

Figure 1

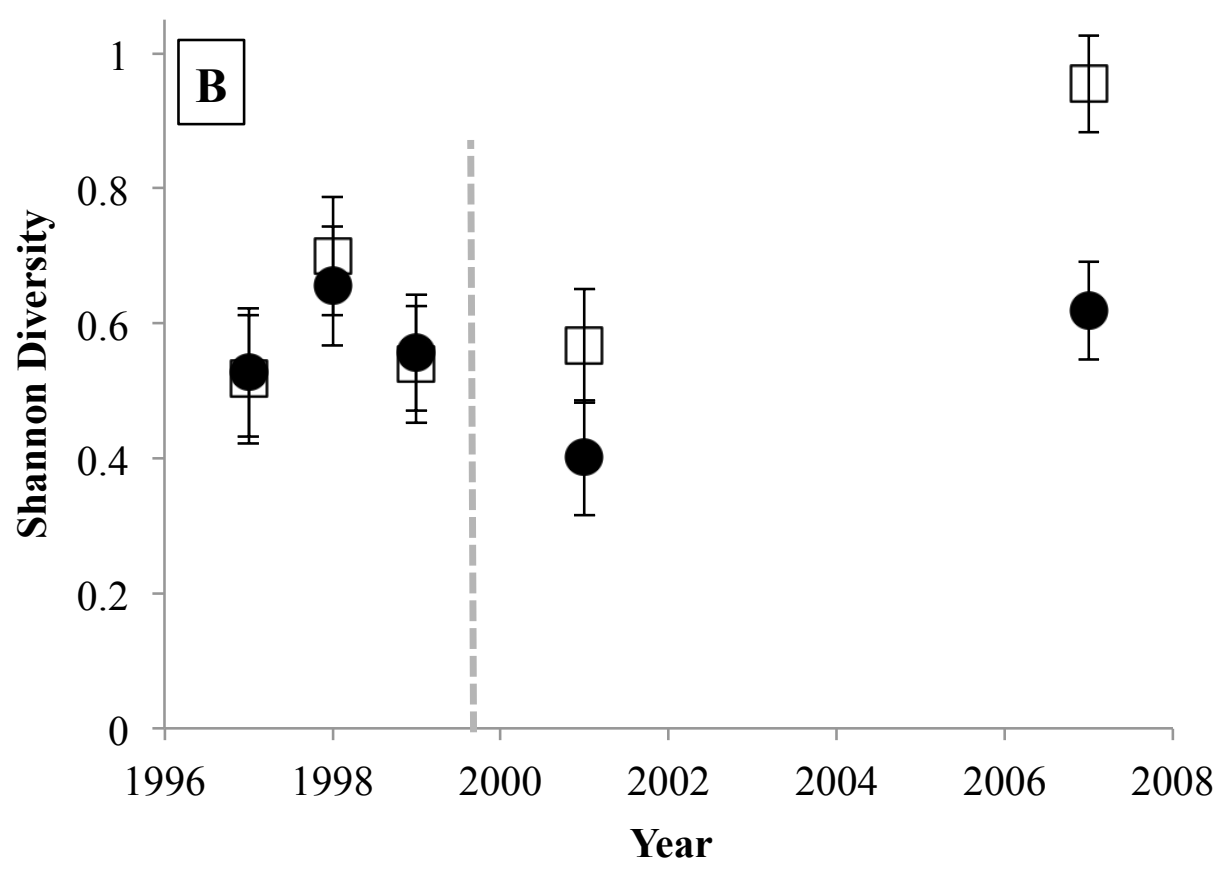




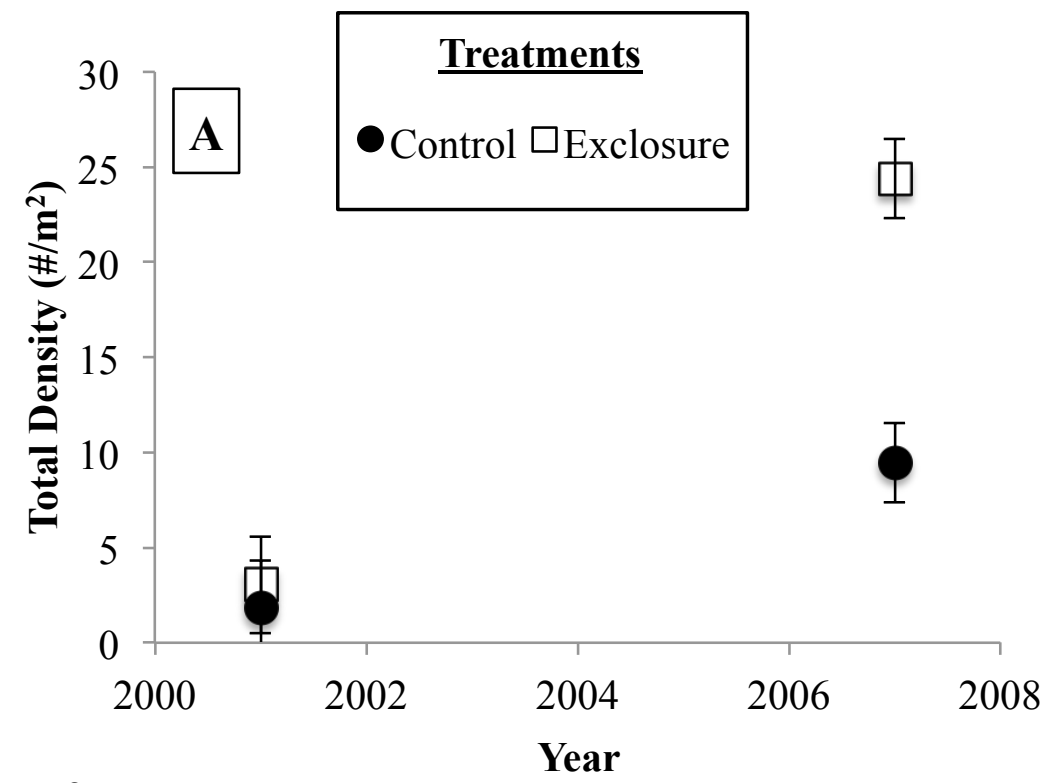

Figure 2
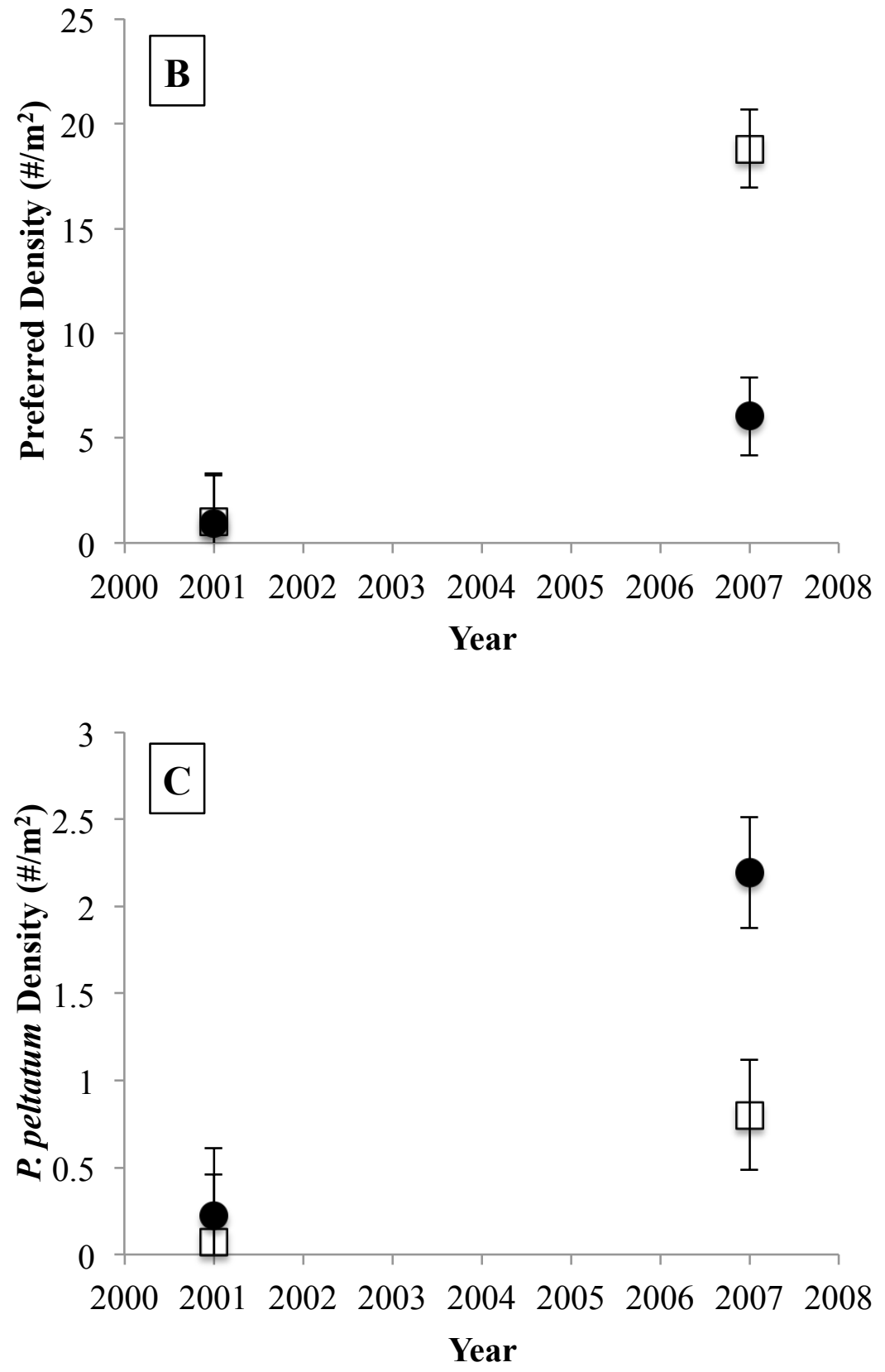

https://mc06.manuscriptcentral.com/cjfr-pubs 


\section{Figure 3}

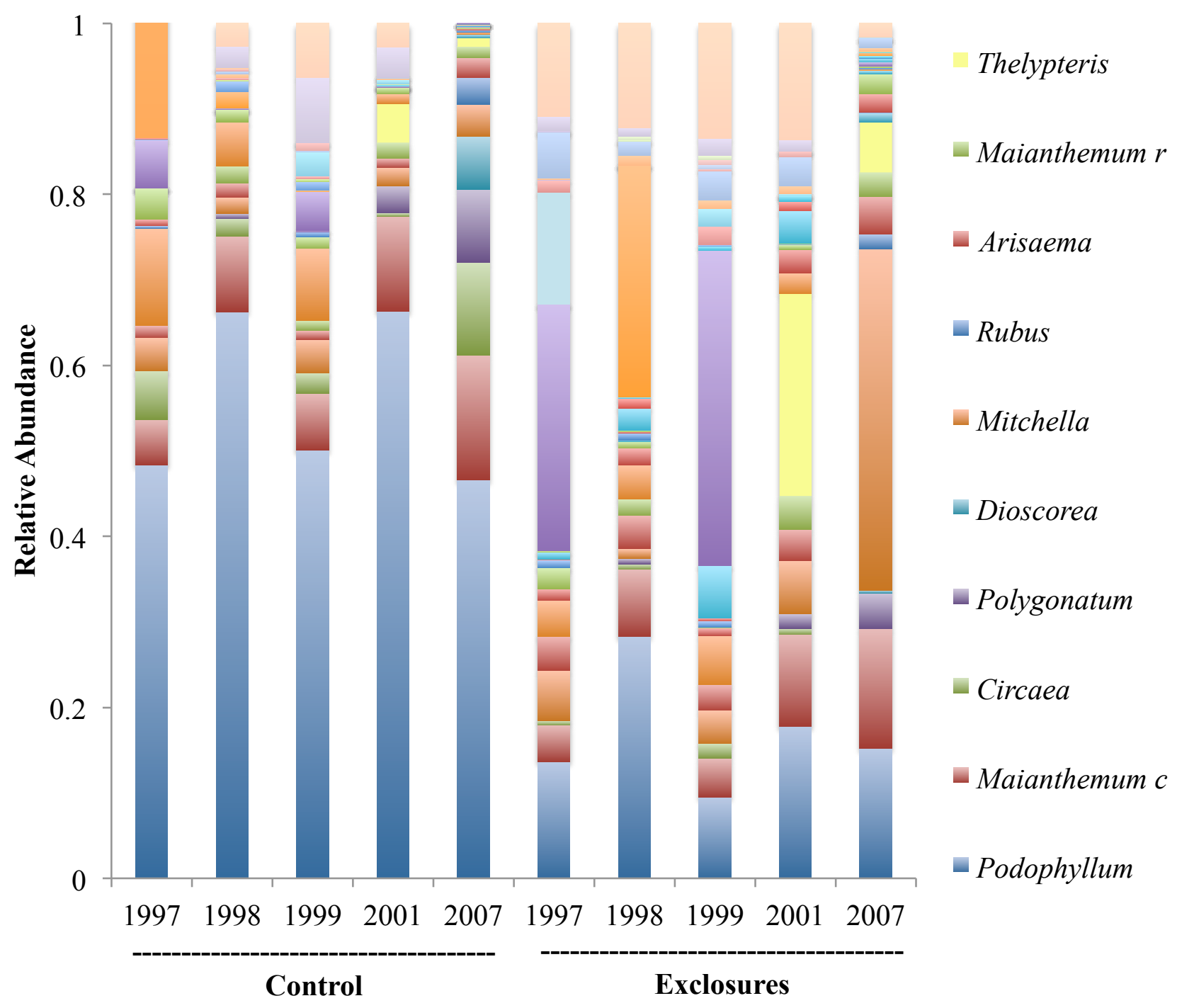




\section{Appendix A}

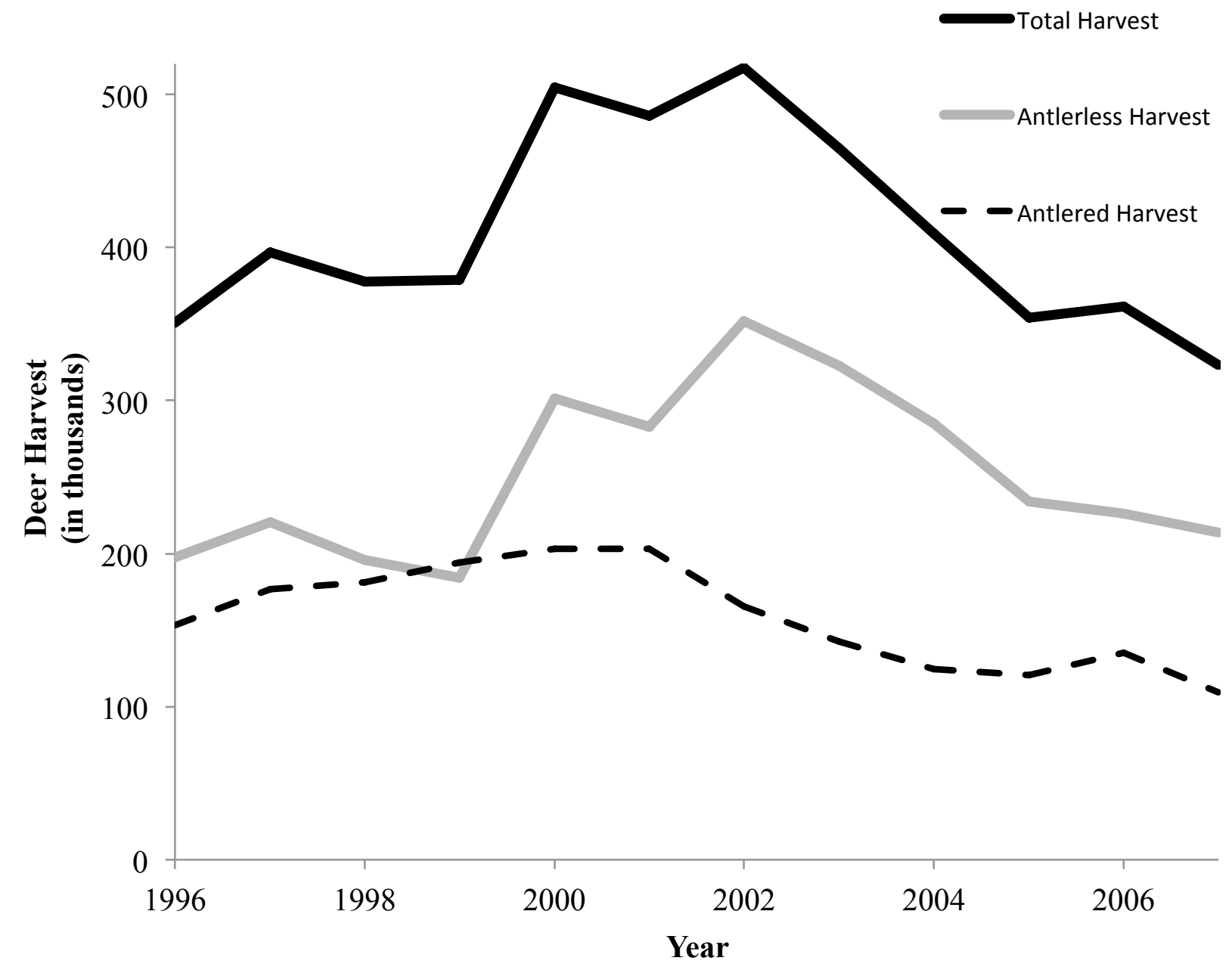

Appendix A. Between 2000 and 2004, Pennsylvania increased the number of antlerless deer tags, resulting in 55\% increase in antlerless (largely doe) deer harvest. Deer densities decreased to approximately 14 deer/kilometer ${ }^{2}$ in 2004 but increased to 20 deer/kilometer ${ }^{2}$ by 2006 (Rosenberry et al. 2011). Deer harvest data obtained from the Pennsylvania Game Commission website (www.pgc.state.pa.us) 
Appendix B. Relative abundance, by cover, of all wildflower species sampled in 1997, 1998, 1999, 2001, and 2007. For breviety and possible identification issues, we have combined data for species in the Actaea, Discorea, Galium, and Viola genera.

\begin{tabular}{|c|c|c|c|c|c|c|c|c|c|c|}
\hline \multirow[b]{2}{*}{ Species } & \multicolumn{5}{|c|}{ Control } & \multicolumn{5}{|c|}{ Exclosure } \\
\hline & 1997 & 1998 & 1999 & 2001 & 2007 & 1997 & 1998 & 1999 & 2001 & 2007 \\
\hline Actaea spp. & 0 & 0 & 0 & 0 & 0 & 0.00818 & 0.02568 & 0.06085 & 0.03752 & 0.00489 \\
\hline Arisaema triphyllum (L.) Schott & 0.01433 & 0.01646 & 0.01053 & 0.01095 & 0.02298 & 0.03983 & 0.03852 & 0.02993 & 0.03683 & 0.04385 \\
\hline Asarum canadense L. & 0 & 0 & 0 & 0 & 0 & $1.6 \mathrm{E}-05$ & 0 & 0 & 0 & 0 \\
\hline Carex spp. & 0.03647 & 0.0144 & 0.01353 & 0.0076 & 0.00133 & 0.02454 & 0.00803 & 0.001 & 0.00546 & 0.02362 \\
\hline Chimaphila maculata (L.) Pursh & 0 & 0 & 0 & 0 & 0 & 0 & 0 & 0 & 0 & $9.4 \mathrm{E}-05$ \\
\hline Circaea lutetiana $L$ & 0.05666 & 0.02058 & 0.02406 & 0.00395 & 0.10851 & 0.00533 & 0.00642 & 0.01696 & 0.00728 & 0 \\
\hline $\begin{array}{l}\text { Claytonia virginica L. var. } \\
\text { virginica }\end{array}$ & 0 & 0 & 0 & 0 & 0 & 0 & 0.01124 & 0 & 0.01137 & 0 \\
\hline Comandra umbellata (L.) Nutt. & 0 & 0 & 0 & 0 & 0 & 0.00164 & 0 & 0 & 0 & 0 \\
\hline $\begin{array}{l}\text { Dennistaedtia punctiloba } \\
\text { (Michx.) T. Moore }\end{array}$ & 0.056 & 0 & 0.04511 & 0 & 0 & 0.28788 & 0 & 0.36911 & 0 & 0 \\
\hline Dioscorea spp. & 0 & 0 & 0 & 0 & 0.06182 & 0 & 0 & 0 & 0 & 0.00339 \\
\hline $\begin{array}{l}\text { Disporum lanuginosum (Michx.) } \\
\text { G. Nicholson }\end{array}$ & 0 & 0 & 0 & 0.00152 & 0 & 0 & 0.00161 & 0.00499 & 0.00682 & 0.00263 \\
\hline $\begin{array}{l}\text { Dryopteris carthusiana (Vill.) } \\
\text { H.P. Fuchs }\end{array}$ & 0 & 0.01852 & 0.0015 & 0 & 0 & 0 & 0.27127 & 0 & 0 & 0.00376 \\
\hline $\begin{array}{l}\text { Epifagus americana (L.) W. } \\
\text { Bartram }\end{array}$ & 0.00132 & 0.01235 & 0.01053 & 0 & 0 & 0.00025 & 0 & 0.001 & 0 & 0 \\
\hline Fragaria virginia Duchesne & 0.0013 & 0 & 0 & 0 & 0 & 0 & 0 & 0 & 0 & 0 \\
\hline Galium spp. & 0.114 & 0.05144 & 0.08421 & 0.01156 & 0.00252 & 0.04212 & 0.04013 & 0.05736 & 0.02478 & 0 \\
\hline Geranium maculata L. & 0.00052 & 0.00206 & 0.00301 & 0 & 0 & 0 & 0 & 0 & 0 & 0 \\
\hline Geum canadense Jacq. & 0 & 0 & 0 & 0 & 0 & 0.13086 & 0 & 0 & 0 & 0 \\
\hline Gleochoma hederaceae L. & 0 & 0 & 0 & 0 & 0 & $6.5 \mathrm{E}-05$ & 0 & 0 & 0 & 0.00038 \\
\hline Impatiens pallida Nutt. & 0 & 0 & 0 & 0 & 0.00015 & 0 & 0.00161 & 0 & 0.00136 & 0.00141 \\
\hline
\end{tabular}




\begin{tabular}{|c|c|c|c|c|c|c|c|c|c|c|}
\hline Ipomoea pandurata (L.) G. Mey. & 0 & 0 & 0 & 0 & 0 & 0 & 0 & 0 & 0 & 0.00019 \\
\hline Lycopodium complanatum L. & 0.00781 & 0 & 0 & 0 & 0.00148 & 0.01349 & 0.01926 & 0.00898 & 0.02729 & 0.02174 \\
\hline Maianthemum canadense Desf. & 0.05356 & 0.08848 & 0.06617 & 0.11131 & 0.14617 & 0.04253 & 0.07865 & 0.04589 & 0.10778 & 0.13993 \\
\hline $\begin{array}{l}\text { Maianthemum stellatum (L.) } \\
\text { Link }\end{array}$ & 0.03543 & 0.00206 & 0.00301 & 0 & 0 & 0.01358 & 0 & 0.02195 & 0 & 0 \\
\hline Mianthemum racemosum L. & 0 & 0.02058 & 0.01203 & 0.01825 & 0.01357 & 0 & 0.01926 & 0 & 0.03865 & 0.02785 \\
\hline Mitchella repens L. & 0.03875 & 0.01852 & 0.0391 & 0.02099 & 0.0371 & 0.05889 & 0.01124 & 0.03891 & 0.06207 & 0.39917 \\
\hline Monotropa uniflora L. & 0 & 0 & 0 & 0 & 0.00119 & 0 & 0.00161 & 0 & 0 & 0.00376 \\
\hline Onoclea sensibilis L. & 0 & 0 & 0 & 0 & 0.00133 & 0 & 0 & 0 & 0 & 0 \\
\hline $\begin{array}{l}\text { Osmorhiza claytonii (Michx.) } \\
\text { C.B. Clarke }\end{array}$ & 0 & 0 & 0.00602 & 0 & 0.00059 & 0.00867 & 0.00803 & 0.00698 & 0.00068 & 0.0016 \\
\hline $\begin{array}{l}\text { Parthenocissus quinquefolia (L.) } \\
\text { Planch. }\end{array}$ & 0 & 0 & 0 & 0.00061 & 0 & 0 & 0 & 0 & 0 & 0.00085 \\
\hline Phytolaca americana $\mathrm{L}$. & 0 & 0.66255 & 0 & 0 & 0 & 0.00123 & 0.2825 & 0 & 0 & 0 \\
\hline Poasp. & 0.0026 & 0 & 0 & 0 & 0.00237 & 0 & 0 & 0 & 0 & 0.00075 \\
\hline Podophyllum peltatum L. & 0.4832 & 0.00412 & 0.50075 & 0.66302 & 0.46592 & 0.13658 & 0.01124 & 0.09477 & 0.17735 & 0.15188 \\
\hline $\begin{array}{l}\text { Polygonatum biflorum (Walter) } \\
\text { Elliot }\end{array}$ & 0 & 0.00617 & 0.02857 & 0.00517 & 0 & 0 & 0.00642 & 0.02045 & 0.00159 & 0 \\
\hline $\begin{array}{l}\text { Polygonatum pubescens (Willd.) } \\
\text { Pursh }\end{array}$ & 0 & 0 & 0 & 0.03193 & 0.08539 & 0 & 0 & 0 & 0.01705 & 0.04187 \\
\hline Polygonum spp. & 0.00912 & 0 & 0 & 0 & 0 & 0.00147 & 0 & 0.00998 & 0 & 0.00395 \\
\hline Polygonum virginianum L. & 0 & 0 & 0 & 0.00182 & 0 & 0 & 0 & 0 & 0.0091 & 0 \\
\hline $\begin{array}{l}\text { Polystichum acrostichoides } \\
\text { (Michx.) Schott }\end{array}$ & 0 & 0 & 0 & 0 & 0.00119 & 0 & 0 & 0 & 0 & 0.00207 \\
\hline Potentilla simplex Michx. & 0.0293 & 0.00412 & 0.0015 & 0.00091 & 0 & 0.05398 & 0.01605 & 0.03382 & 0.03456 & 0.01214 \\
\hline Pyrola elliptica Nutt. & 0 & 0.00206 & 0.00902 & 0 & 0 & 0 & 0 & 0.00299 & 0.00682 & 0 \\
\hline Ranunculus sp. & 0 & 0 & 0 & 0 & 0 & 0 & 0.00161 & 0 & 0 & 0 \\
\hline Rubus sp. & 0 & 0 & 0 & 0 & 0.03158 & 0 & 0 & 0 & 0 & 0.01731 \\
\hline
\end{tabular}




\begin{tabular}{|c|c|c|c|c|c|c|c|c|c|c|}
\hline Sanicula sp. & 7.8E-05 & 0 & 0 & 0 & 0 & 0.00164 & 0 & 0 & 0 & 0 \\
\hline Smilax spp. & 0 & 0 & 0 & 0 & 0.0003 & 0.00164 & 0.00161 & 0.00399 & 0 & 0 \\
\hline $\begin{array}{l}\text { Sphagnum platyphyllum (Lindb. } \\
\text { ex Braithw.) Sull. ex Warnst. }\end{array}$ & 0.0026 & 0 & 0 & 0 & 0 & 0 & 0 & 0 & 0 & 0 \\
\hline Symphyotrichum sp. & 0 & 0.00206 & 0 & 0 & 0 & 0 & 0 & 0 & 0 & 0 \\
\hline $\begin{array}{l}\text { Thelypteris noveboracensis (L.) } \\
\text { Nieuwl. }\end{array}$ & 0 & 0 & 0 & 0.04562 & 0.00993 & 0 & 0 & 0 & 0.23647 & 0.05938 \\
\hline $\begin{array}{l}\text { Toxicodendron radicans (L.) } \\
\text { Kuntze }\end{array}$ & 0 & 0 & 0 & 0 & 0.00445 & 0 & 0 & 0 & 0 & 0.01035 \\
\hline Trientalis borealis Raf. & 0 & 0 & 0 & 0 & 0 & 0 & 0 & 0.00499 & 0 & 0 \\
\hline $\begin{array}{l}\text { Trillium grandiflorum (Michx.) } \\
\text { Salisb. }\end{array}$ & 0 & 0.00206 & 0.0015 & 0.00152 & 0.00015 & 0 & 0 & 0 & 0 & 0.00452 \\
\hline Triodanis sp. & 0 & 0 & 0 & 0 & 0 & 0 & 0.00161 & 0.00599 & 0 & 0 \\
\hline Urtica dioica L. & 0 & 0 & 0 & 0 & 0 & 0 & 0.00482 & 0.00449 & 0 & 0 \\
\hline Uvularia perfoliata $\mathrm{L}$. & 0.0086 & 0.02469 & 0.07669 & 0.03558 & 0 & 0.01636 & 0.00963 & 0.01995 & 0.01296 & 0 \\
\hline Veronica officinale L. & 0 & 0 & 0 & 0 & 0 & 0 & 0 & 0 & 0 & 0.00075 \\
\hline Viola spp. & 0.04836 & 0.02675 & 0.06316 & 0.02768 & 0 & 0.10926 & 0.12199 & 0.13468 & 0.1362 & 0.0159 \\
\hline
\end{tabular}

